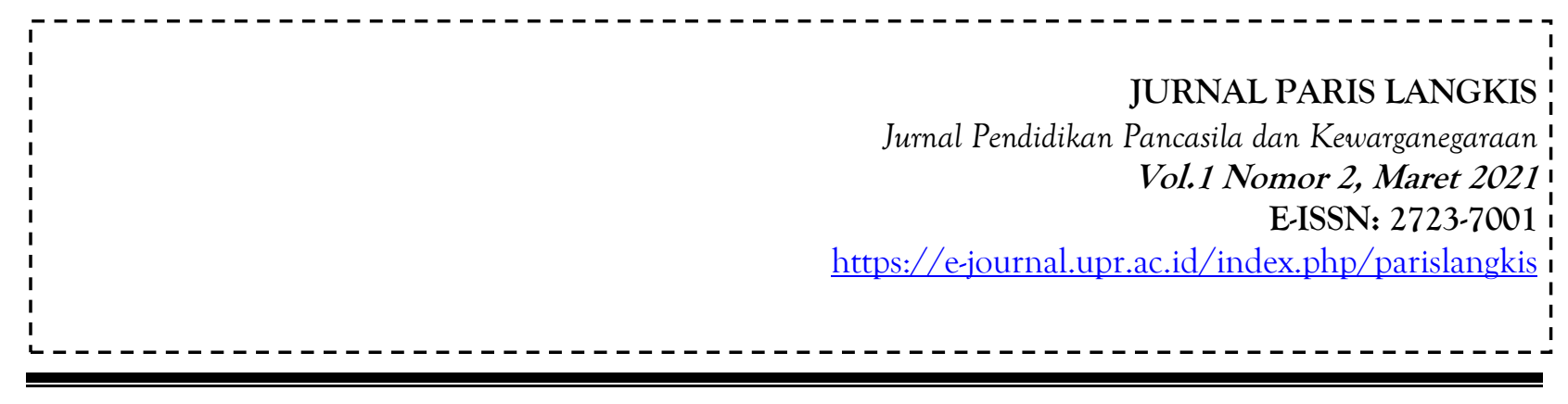

\title{
PERILAKU NASIONALISME MASYARAKAT DI ERA KEMAJUAN TEKNOLOGI DAN INFORMASI PADA MASYARAKAT SAMIN DI KABUPATEN BOJONEGORO
}

\author{
Muhammad Faisal Kurniawan $^{1}$, Siti Awaliyah ${ }^{2}$, Muhammad Mujtaba Habibi $^{3}$ \\ 1,2,3 Program Studi Pendidikan Pancasila dan Kewarganegaraan \\ Universitas Negeri Malang \\ muhammad.faisal.1707116@students.um.ac.id ${ }^{1}$, siti.awaliyah.fis@um.ac.id ${ }^{2}$,.m.mujtaba.fis@um.ac.id ${ }^{3}$
}

\begin{abstract}
Abstrak
kajian ini membahas permasalahan tentang penerapan nilai Nasionalisme di era kemajuan teknolofgi dan informasi pada masyarakat Samin di Dusun Jepang Kecamatan Margomulyo Kabupaten Bojnegoro sebagai wujud manifestasi dari ajaran Saminisme yang masyarakat Samin ikuti dan mereka warisi dari leluhurnya. Kajian ini menggunakan pendekatan kualitatif yang bersifat deskriptif dengan melakukan deskripsi dengan kenyataan dilapangan. Pengumpulan data dilakukan dengan observasi, wawancara, dan dokumentasi. Analisis data menggunakan analisis kualitatif yang terdiri dari reduksi data, verifikasi data dan penarikan kesimpulan. Hasil dari penelitian ini menunjukan tiga bentuk nilai Nasionalisme yang ada dalam ajaran Saminisme yaitu nilai kesatuan, nilai solidaritas dan nilai kemandirian. Pendapat masyarakat Samin mengenai keberadaan teknologi dan informasi yaitu hadirnya teknologi dan informasi dapat memudahkan pekerjaan mereka sehari-hari sehingga mereka dapat menerima masuknya teknologi. Penerapan nilai Nasionalisme di era kemajuan teknologi dan informasi pada masyarakat Samin diwujudkan dalam berbagai perilaku yaitu menjaga ketertiban dengan mematuhi aturan yang berlaku, menghormati dan tidak membeda-bedakan sesama, gotong royong dan saling tolong menolong, mencintai produk sendiri dan aktif dalam pembangunan bangsa dan negara.

Kata Kunci: Samin; Nasionalisme; Teknologi
\end{abstract}

\section{Abstract}

This study discusses the problem of applying the value of Nationalism in the era of technological advancement and information to the Samin community in Jepang Hamlet, Margomulyo District, Bojnegoro Regency as a manifestation of the Saminism teachings that the Samin people follow and they inherit from their ancestors. This

\section{Paris Langkis}

Vol.1 Nomor 2, Maret 2021 
study uses a descriptive qualitative approach by conducting descriptions in the field. Data collection was carried out by observation, interviews, and documentation. Data analysis used qualitative analysis consisting of data reduction, data levers and data collection. The results of this study indicate three forms of nationalism values that exist in the teachings of Saminism, namely the value of unity, the value of solidarity and the value of independence. The opinion of the people of Samin regarding the existence of technology and information is that the presence of technology and information can facilitate their daily work so that they can accept the entry of technology. The application of the value of Nationalism in the era of advances in technology and information in the Samin community is manifested in various behaviors, namely monitoring of order by complying with applicable rules, respecting and not discriminating against fellow products, mutual cooperation and mutual help, loving yourself and being active in the development of the nation and state.

Keywords: Samin; Nationalism; Technology

\section{A. PENDAHULUAN}

Masyarakat Samin merupakan komunitas masyarakat asli Jawa yang terkenal memiliki berbagai keunikan tersendiri yang membedakan dari masyarakat lainnya. Perbedaan tersebut yaitu dari adat dan budayanya yang mereka warisi secara turun temurun dari leluhurnya. Masyarakat Samin dalam kepribadian yaitu memiliki watak yang polos dan jujur. Mereka beranggapan bahwa setiap orang adalah saudara atau keluarga, hal ini menyebabkan kebersamaan selalu menjadi hal yang utama. Menjadi jujur selalu tercermin dalam tingkah laku sehari-hari. Apa yang diucapkan merupakan fakta yang sesuai dengan yang mereka alami. Mereka tidak pernah merekayasa suatu hal. Jujur merupakan salah satu implementasi dari ajaran yang dipegangnya. Selain itu, mereka juga menerapkan prinsip kesamaan atau egaliter. Prinisp ini dapat dilihat dari cara komunikasi mereka yang memakai Bahasa Jawa Ngoko Lugu yang merupakan Bahasa Jawa tanpa mengenal tingkatan ketika berkomunikasi.

Menurut sejarahnya, masyarakat Samin memiliki kebudayaan yaitu suatu ajaran yang mereka warisi dari pendahulunya. Ajaran tersebut terkenal dengan sebutan ajaran Samin atau Saminisme. Ajaran ini pertama kali dicetuskan oleh Samin Surosentiko yang merupakan Samin generasi pertama dan sekaligus sebagai pendiri masyarakat Samin. Samin Surosentiko menyebarkan ajaran Samin pada awalnya di daerah Klopoduwur, Kabupaten Blora. Kemudian seiring berjalannya waktu, ajaran ini menyebar ke berbagai wilayah yang meliputi Rembang, Kudus, Pati, Ngawi, dan juga Bojonegoro. Berdirinya Masyarakat Samin sendiri disebabkan karena kondisi pada waktu itu sedang dijajah oleh penjajahan Belanda yang pada waktu itu sangat menindas kepada masyarakat Indonesia khususnya adalah masyarakat Jawa. Sehingga masyarakat Samin ini muncul sebagai bentuk gerakan perlawanan atas kondisi tersebut.

Masyarakat Samin dalam melakukan perlawanan terhadap penjajahan Belanda dilakukan dengan perlawanan tanpa kekerasan yakni dengan perilaku-perilaku yang aneh dan nyeleneh. Perlawanan tersebut salah satunya yaitu dengan tinggal di tempat terpencil dan mengisolasi diri dari kehidupan luar. Selain itu, perlawanan mereka juga ditunjukan dalam menolak pendidikan karena mereka beranggapan bahwa sekolah itu miliknya Belanda dan apabila mereka sekolah nanti malah menjadi antek Belanda. Sehingga dari hal tersebut, banyak yang beranggapan bahwa masyarakat Samin ini identik dengan masyarakat yang tertinggal.

\section{Paris Langkis}

Vol.1 Nomor 2, Maret 2021 
Saat ini masyarakat Samin kondisinya sudah berbeda dengan kondisi mereka pada awal berdirinya, mereka sekarang telah mau membuka diri dengan dunia luar. Mereka sekarang telah memakai berbagai macam teknologi baik itu teknologi dalam hal pertanian, teknologi komunikasi dan berbagai macam teknologi lainnya. Selain itu mereka juga telah ada yang mengenyam pendidikan sampai ke perguruan tinggi, berprofesi sebagai polisi, guru, PNS dan lain-lain. Serta banyak dari mereka yang telah memiliki pemikiran yang maju dan modern. Sehingga kesan yang menyebutkan bahwa masyarakat Samin adalah masyarakat yang terbelakang dan keterasingan akan modernisasi menjadi tidak sesuai bila diterapkan pada kondisi mereka saat ini. Ditambah lagi dengan adanya pembangunan Desa Wisata Budaya yang menawarkan kebudayaan Samin sebagai destinasi wisata menjadikan semakin cepatnya perkembangan teknologi dan informasi masuk ke Dusun Jepang.

Masuknya arus perkembangan teknologi dan informasi dalam kehidupan masyarakat Samin telah membawa perubahan pada kehidupan masyarakat Samin. Sejalan dengan pendapat Tashadi (dalam Munawaroh, dkk, 2015:8) dalam hasil penelitiannya yang menerangkan bahwa telah banyak perubahan yang terjadi dalam kehidupan sehari-hari masyarakat Samin yang mana perubahan ini selaras dengan mulai masuknya arus globalisasi dalam kehidupan mereka. Arus globalisasi ini membawa dampak positif dan negatif bagi kehidupan masyarakat Samin. Dampak positifnya yaitu ditandai dengan gaya hidup serta pola atau cara berpikir masyaraknya yang modern. Sedangkan dampak negatifnya yaitu mulai terkikis dan ditinggalkannya budaya dan tradisi Samin yang mereka warisi dari leluhurnya. Kemudian dipertegas dengan pendapat Lestari (2013:74-86) dalam penelitiannya yang berpendapat bahwa dalam kehidupan masyarakat Samin telah terjadi proses transisi dari yang semula adalah masyarakat tradisional menuju masyarakat yang modern yang ditandai dengan interaksi sosial asosiatif dan disosiatif pada masyarakat Samin. Interaksi sosial asosiatif ditunjukan masih adanya kerjasama dan tolong menolong, sedangkan interaksi disosiatif ditunjukan dengan kecemburuan sosial pada masyarakat Samin ketika ada bantuan dari pemerintah yang datang ke Dusun Jepang. Selanjutnya disamping pengaruh dari perkembangan teknologi dan informasi yang ditunjukan dari perubahan yang terjadi pada kehidupan mereka, masyarakat Samin masih menganut ajaran Samin yang mereka warisi dari leluhurnya. Sesuai dengan pendapat Widyatwati (2017:137-146) dalam penelitianya yang menyatakan bahwa komunitas masyarakat samin masih tetap konsisten dalam ajaran yang mereka anut, meskipun pola pikirnya telah berubah menjadi lebih modern.

Berdasarkan penjelasan tersebut dapat diambil kesimpulan bahwasanya perkembangan teknologi dan informasi yang sejalan dengan arus globalisasi dapat menyebabkan perubahan sosial dalam masyarakat. Hal ini yang menjadi masalah yang ingin dikaji oleh peneliti dalam penelitiannya yang mengkaji tentang perilaku Nasionalisme masyarakat di era kemajuan teknologi dan informasi pada masyarakat Samin. sehingga hal ini menjadi menarik karena masyarakat Samin tetap memegang teguh ajaran Saminisme yang diwariskan dari pendahulunya yang mana sebagian isi dari ajaran tersebut mengenai nilai-nilai nasionalisme. Berdasarkan uraian yang telah dijabarkan tersebut, peneliti ingin mengkaji dan mendalami mengenai bagaimana perilaku Nasionalisme masyarakat Samin di era kemajuan teknologi dan informasi.

\section{Paris Langkis}

Vol.1 Nomor 2, Maret 2021 


\section{B. KAJIAN TEORI}

\section{Teori Terbentuknya Perilaku}

a. Pengertian Perilaku

Pengertian perilaku menurut Wardiah (2016:14) menjelaskan bahwa perilaku adalah semua kegiatan, aktifitas atau tingkah laku manusia, baik yang bisa diamati secara langsung maupun yang tidak bisa diamati pihak luar. Kemudian pengertian perilaku juga dijelaskan oleh Skinner sebagaimana dikutip Wardiah (2016:15) yang merumuskan bahwa "perilaku merupakan respon atau reaksi seseorang terhadap stimulus (rangsangan dari luar)". Oleh karena itu perilaku menurut Skinner terjadi melalui tahapan proses stimulus kepada organisme, serta kemudian organisme yang diberi stimulus tersebut merespon, teori perilaku menurut skinner ini disebut dengan teori "S-O-R" atau stimulus-organisme-respon. Jadi dapat disimpulkan bahwa perilaku adalah kegiatan, aktivitas, maupun tingkah laku dari manusia yang diakibatkan adanya interaksi dengan kelompok maupun lingkungannya yang mana kegiatan, aktivitas, maupun tingkah laku ini bisa diamati secara langsung maupun tidak bisa diamati pihak luar.

b. Cara Terbentuknya Perilaku

Proses terbentuknya perilaku dikemukakan oleh Eduard Spranger sebagaimana yang dikutip oleh Wardiah (2016:21) yaitu perilaku manusia timbul karena hasil refleksi dari bermacam-macam gejala kejiwaan seseorang, seperti pengetahuan, keinginan, kehendak, motivasi, minat dan sebagainya. Akan tetapi dari pendapat tersebut sulit untuk dideteksi apakah gejala kejiwaan yang menentukan dari perilaku seseorang. Apabila diteliti lebih lanjut tentang penyebab dari gejala kejiwaan yaitu dipengaruhi oleh berbagai faktor, seperti pengalaman, keyakinan, fisik, dan lain-lain. c. Faktor-faktor Yang Mempengaruhi Perilaku

Faktor yang mempengaruhi perilaku individu dalam berkelompok juga diungkapkan oleh Mc. Gregor (dalam Wardiah, 2016:39), yakni meliputi: (a) atmosfer, yaitu kondisi yang rileks serta nyaman yang bebas dari tekanan, disaat individu bisa mudah berinteraksi serta terlibat; (b) diskusi, yaitu fokus berpartisipasi pada setiap orang; (c) tujuan/objektif, yaitu dapat dipahami dengan jelas serta dapat diterima oleh seluruh anggota kelompok; (d) listening, yaitu anggota akan aktif mendengarkan anggota yang lain; (e) disagremeent (pertentangan), yaitu bila terjadi perselisihan pendapat ataupun pandangan, kelompok merasa bisa menghadapi semuanya dengan nyaman; (f) keputusan, dibuat secara konsensus/ dengan persetujuan umum/ mufakat; (g) critisim, terbuka, tidak ada jadwal agenda kegiatan yang disembunyikan, sehingga anggota dapat merasakan kenyamanan; (h) feeling, dapat mengekspresikan dengan bebas; (i) action, dengan jelas ditegaskan serta anggota memiliki komitmen; (j) leadership, tidak adanya perebutan kekuasaan; ( $\mathrm{k}$ ) kesadaran diri, kelompok memiliki tanggung jawab penuh dengan cara kerja.

d. Bentuk-bentuk Perilaku

Menurut Sukijo sebagaimana yang dikutip oleh Wardiah (2016:15) perilaku jika dilihat dari bentuk respons dari stimulus dapat dibedakan menjadi dua yaitu: (1) Perilaku tertutup, perilaku tertutup adalah respon yang didapat seseorang dari stimulus dalam suatu bentuk terselubung atau tertutup. Respon dari stimulus ini terbatas pada perhatian, persepsi, pengetahuan, kesadaran, serta sikap yang timbul pada seseorang yang mendapat stimulus dan belum bisa nampak secara jelas bila diamati oleh orang lain; dan (2) Perilaku terbuka, perilaku terbuka adalah respon dari seseorang

\section{Paris Langkis}

Vol.1 Nomor 2, Maret 2021 
yang disebabkan oleh diterimanya stimulus dalam wujud tindakan nyata dan secara terbuka. Respons dari stimulus tersebut terlihat jelas dalam bentuk tindakan atau perilaku yang mudah dapat diamati oleh orang lain.

e. Proses Adopsi Perilaku

Ptoses adopsi perilaku diungkapkan oleh Notoatmodjo sebagaimana dikutip oleh Wardiah (2016:20) bahwa sebelum seseorang mengadopsi atau memakai perilaku baru, dalam diri seseorang tersebut terjadi proses-proses yang berurutan, proses-proses tersebut yaitu: (1) awareness, awareness yaitu proses disadarinya stimulus (objek) lebih dahulu; (2) interest, interest yaitu proses ketertarikan kepada simulus; (3) evaluation, evaluation yaitu proses menimbang baik atau buruknya stimulus tersebut untuk dirinya; (4) trial, trial adalah proses mencoba perilaku yang baru; (5) adaption, adaption yaitu proses berperilaku baru sesuai dengan pengetahuan, kesadaran serta sikapnya terhadap rangsangan atau stimulus.

\section{Teknologi Informasi}

Pengertian teknologi menurut Anglin sebagaimana dikutip oleh Arifin (2012:92) bahwa teknologi merupakan penerapan ilmu-ilmu perilaku dan alam serta pengetahuan lain secara bersistem dan menyistemkan untuk memecahkan masalah. Dalam hal ini tujuan adanya teknologi secara jelas mengarah langsung kepada suatu hal yang dapat memudahkan kinerja umat manusia. Dengan adanya teknologi, pekerjaan manusia akan dipermudah serta dapat dipercepat. Selain mempermudah kehidupan manusia, keberadaan teknologi juga menjadi faktor yang dapat merubah kehidupan sosial. Faktor tersebut adalah penemuan baru yang dapat dibedakan dalam pengertian discovery dan invention. Discovery adalah penemuan unsur kebudayaan baru baik berupa alat maupun yang berupa gagasan yang diciptakan oleh seorang individu. Discovery baru menjadi invention kalau masyarakat sudah mengakui, menerima serta menerapkan penemuan baru itu. Seperti halnya aplikasi media sosial yang telah diterapkan dan diaplikasikan oleh masyarakat. hal ini merupakan keterkaitan modernisasi dan globalisasi dalam proses perubahan sosial dalam masyarakat (Nasution, 2017:31). Oleh karena itu kebudayaan lokal dari suatu negara menjadi rawan untuk punah ataupun berubah tergerus oleh perkembangan teknologi dan informasi.

\section{Masyarakat Samin}

Masyarakat Samin merupakan sebuah fenomena budaya yang memiliki keunikan dan sekaligus memiliki banyak sarat akan pesan. Masyarakat ini terbentuk karena adanya Kolonialisme yang dilakukan oleh Belanda yang pada waktu itu sangat menindas kepada rakyat Indonesia. mereka melakukan perampasan, pembunuhan dan bahkan sampai kerja paksa tanpa upah. Sehingga pada waktu itu Surosentiko Samin mendirikan masyarakat Samin sebagai suatu tindakan perlawanan kepada penjajahan Belanda. Akan tetapi perlawanan tersebut dilakukan bukan dengan kekerasan, melainkan perlawanan dengan tindakan yang nyeleneh dan ngawur. Perlawanan tersebut dilakukan atas dasar implementasi dari ajaran Samin yang terus mereka yakini hingga sekarag. Aajaran itu lebih dikenal sebagai ajaran Samin atau Saminisme. Menurut Kistanto (dalam Norhalisa, Lion, Dotrimensi, 2020:16-17) yang menyatakan bahwa "kebudayaan adalah suatu sistem gagasan dan rasa, tindakan serta karya yang dihasilkan manusia dalam kehidupan bermasyarakat, yang

\section{Paris Langkis}

Vol.1 Nomor 2, Maret 2021 
dimilikinya dengan belajar". Sesuai dari pernyataan tersebut, ajaran Samin sebagai sebuah kebudayaan timbul karena proses belajar yang dilakukan oleh pendiri Masyarakat Samin yaitu Samin Surosesntiko atas kondisi pada waktu itu yaitu bangsa Indonesia tengah dijajah oleh Kolonialisme Belanda yang waktu itu sangat menindas kepada masyarakat pribumi.

Ajaran Samina tau Saminisme menurut Widyatwati (2017:141) mempunyai pokok ajaran meliputi: (a) Agama itu pegangan hidup: (b) Tidak boleh mengusik orang lain, tidak boleh bertengkar, tidak boleh suka iri hati, dan tidak boleh suka mencuri barang dari orang lain: (c) Bersikap sabar serta tidak boleh sombong: (d) Manusia dalam hidupnya harus paham akan kehidupannya sebab hidup merupakan roh dan cuma satu, selamanya: dan (e) Bila bercakap masyarakat Samin harus bisa menjaga diri, jujur, dan saling menghormati. Ajaran samin beranggapan bahwa Perdagangan dilarang karena dalam perdagangan ada ketidakjujuran. Ajaran samin juga melarang masyarakat samin untuk menerima sumbangan berbentuk uang.

\section{Nilai Nasionalisme}

a. Nilai

Hakikatnya semua objek baik itu benda hidup maupun benda mati yang ada di dunia pasti mempunyai nilai yang menempel pada objek tersebut. Nilai ini melekat dalam bentuk kualitas dari suatu hal tersebut. Hal ini sesuai dengan pernyataan Anas (2017:2) mengemukakan bahwa nilai adalah kualitas yang melekat pada suatu hal. Sesuatu hal atau objek tersebut bisa bernilai jika dipandang dari sudut kegunaan secara material, maupun memiliki nilai dari perspektif kepentingan atau motivasi. Suatu hal apabila mengandung nilai apabila ada sifat atau kualitas yang menempel atau melekat pada suatu hal tersebut. pengertian nilai juga disampaikan Mustari (2011:4) menjelaskan bahwa "Nilai merupakan satu prinsip umum yang menyediakan anggota masyarakat dengan satu ukuran atau standard untuk membuat penilaian dan pemilihan mengenai tindakan dan cita-cita tertentu”. Berdasarkan beberapa pendapat tersebut dapat diambil kesimpulan bahwa nilai adalah sebuah hal yang berbentuk abstrak yang mana hal tersebut adalah suatu kepercayaan oleh seseorang untuk bertindak atau menghindari suatu tindakan, atau mengenai sesuatu yang pantas atau tidak pantas dikerjakan, dimiliki dan dipercaya serta sebagai standar guna menentukan penilaian atau pemilihan mengenai tindakan dan cita-cita tertentu.

b. Nasionalisme

Nasionalisme berasal dari dua kata yaitu nation yang berarti bangsa dan isme yang berarti paham atau aliran. Jadi dapat disimpulkan bahwa Nasionalisme adalah sebuah paham kebangsaan yang dianut oleh masyarakat untuk melindungi dan memajukan bangsanya. pengertian Nasionalisme menurut Stoddard (dalam Supriadi dkk, 2014:2) menjelaskan bahwa "Nasionalisme adalah keadaan rohani, yakni suatu kepercayaan yang dianut sejumlah orang yang mempunyai suatu rasa kebangsaan, suatu perasaan tergolong bersama-sama menjadi bangsa dan negara”. Selanjutnya pengertian Nasionalisme juga diungkapkan oleh Marvin Perry sebagaimana dikutip oleh Alfaqi (2015:112) bahwa "Nasionalisme adalah suatu ikatan sadar yang dimiliki bersama oleh sekelompok orang yang memiliki kesamaan bahasa, kebudayaan dan sejarah yang ditandai dengan kejayaan dan penderitaan bersama dan saling terikat dalam suatu negeri tertentu”. Kemudian Adisusilo (2010:6) mengungkapkan bahwa terdapat faktor yang menimbulkan timbulnya Nasionalisme yaitu di dalam

\section{Paris Langkis}

Vol.1 Nomor 2, Maret 2021 
Nasionalisme terdapat aspek goal yang menunjuk tentang adanya cita-cita atau impian, tujuan maupun suatu harapan ideal secara bersama pada suatu masa yang akan datang yang secara bersama menginginkan untuk diperjuangkan atau diwujudkan di masyarakat atau negara. Jadi dapat disimpulkan bahwa nasionalisme adalah paham yang lahir secara sadar dari seseorang yang disebabkan oleh bermacam-macam cara, mulai dari karena kesamaan akan sejarah, kebudayaan, cita-cita, ketidakadilan, penindasan, serta sebagai wujud perlawanan suatu kelompok bangsa maupun sebagai kesamaan senasib. Dalam paradigma yang baru nasionalisme didefinisikan sebagai suatu bentuk yang memberikan suatu wawasan serta bimbingan bagi suatu bangsa untuk mencapai kesuksesan dan keberhasilan yang dapat menjadikan kehormatan bagi suatu bangsa tersebut. nasionalisme dapat juga diartikan sebagai arah pemikiran serta tujuan yang digunakan guna menanggulangi berbagai permasalahan yang dihadapi oleh suatu bangsa baik itu yang terjadi pada saat ini maupun yang akan dihadapi pada masa depan.

c. Nilai Nasionalisme

Nilai Nasionalisme menurut Sholichiyah (2014:32) mengungkapkan bahwa nilai Nasionalisme itu dapat dikatakan sebagai sebuah perasaan mendalam yang hanya dapat dirasakan, dipikirkan dan serta dihayati oleh masyarakat yang bertempat tinggal dalam suatu negara untuk membela serta mempertahankan negaranya. Dalam hal ini Nilai Nasionalisme bisa dimaknai sebagai cita-cita, harapan serta keharusan guna masa depan dari suatu bangsa, yang mana masa depan bangsa ini terlepas dari perbedaan suku, agama, golongan dan lain-lain. sangatlah berguna dalam membina rasa persatuan antar rakyat atau warga negara yang heterogen atau beragam yang dikarenakan perbedaan suku, agama, ras dan golongan, serta nilai Nasionalisme memiliki fungsi untuk mewujudkan kebersamaan dari seluruh warga negara. Selain itu Nilai Nasionalisme juga terdapat berbagai bentuk yang meliputi nilai kesatuan yaitu dicerminkan dari suatu keinginan untuk bersatu dari masyarakat dalam suatu bangsa yang dikarenakan kesamaan nasib, nilai solidaritas yang dicerminkan dari rasa kepedulian antar sesama dan nilai kemandirian yang digambarkan dengan memiliki prinsip kebebasan, kesamarataan dan kepribadian sebagai suatu nilai dalam kehidupan. (Sholichiyah 2014:43-48)

\section{METODE PENELITIAN}

Penelitian mengenai perilaku Nasionalisme masyarakat di era kemajuan teknologi dan informasi pada masyarakat Samin di Kabupaten Bojonegoro ini menggunakan metode penelitian kualitatif dengan pendekatan deskriptif. Metode dan pendekatan yang dilakukan bertujuan untuk memberikan penjelasan atau penjabaran mengenai perilaku-perilaku yang dilakukan masyarakat Samin dalam melaksanakan nilai-nilai Nasionalisme di era kemajuan teknologi dan informasi. Penelitian ini dilakukan dengan hadir langsung di tempat tinggal masyarakat Samin yaitu di Dusun Jepang, Desa Margomulyo, Kecamatan Margomulyo, Kabupaten Bojonegoro.

Sumber dari penelitian ini meliputi informan, peristiwa, dan dokumen. Informan adalah seseorang yang memberikan informasi terkait yang dibutuhkan dalam penelitian ini. Informan dalam penelitian ini yaitu sesepuh masyarakat Samin Dusun Jepang, masyarakat Samin Dusun Jepang, Kepala Dusun Jepang, Ketua Karang Taruna Dusun Jepang dan Kepala Desa Margomulyo, Peristiwa adalah sebuah aktivitas atau kejadian yang terjadi pada saat peneliti melakukan penelitian

\section{Paris Langkis}

Vol.1 Nomor 2, Maret 2021 
yang berupa pengamatan. Maka dari itu peneliti melakukan pengamatan secara langsung dilapangan dengan langsung terjun ke tempat tinggal masyarakat Samin yaitu di Dusun Jepang, Desa Margomulyo, Kecamatan Margomulyo, Kabupaten Bojonegoro. Sedangkan dokumen adalah data penelitian yang berwujud tertulis maupun berupa foto baik itu dari media cetak maupun online serta video dokumenter Sedulur Sikep Samin Bojonegoro. Dokumen pada penelitian ini yaitu dokumen tertulis mengenai masyarakat Samin Dusun Jepang yang nantinya bertujuan untuk memperkuat hasil dari data yang telah diperoleh dari proses penelitian. Selain itu sumber data pada penelitian ini terdiri dari sumber data primer yang didapatkan secara langsung ketika penelitian dan sumber data sekunder yang didapatkan secara tidak langsung yaitu didapat dari informasi atau dokumentasi.

Teknik pengumpulan data pada penelitian ini yaitu dengan melakukan wawancara, observasi dan studi dokumen atau dokumentasi. Peneliti akan melakukan wawancara secara tidak terstruktur yang mana arah pertanyaannya nanti secara lebih terbuka. Peneliti melakukan wawancara kepada orang atau informan yang mengikuti ajaran Samin atau masyarakat Samin. Observasi dilakukan secara langsung oleh peneliti dengan mengamati peristiwa-peristiwa yang terjadi sesuai dengan pokok bahasan dalam penelitian. Dokumentasi diperoleh dari lapangan atau diperoleh secara langsung dari masyarakat Samin yang berupa foto perilaku masyarakat Samin dalam melaksanakan nilai Nasionalisme sebagai dampak dari globalisasi, kebudayaan masyarakat Samin, kondisi Dusun Jepang secara umum dan dokumen-dokumen cetak yang ada di lokasi penelitian. Penelitian ini menggunakan Teknik analisis data dengan menggunakan model analisis data Miles dan Huberman. Pengujian keabsahan data dilakukan dengan cara uji kredibilitas, Uji kredibilitas yaitu meliputi memperdalam observasi dan triangulasi data.

\section{HASIL DAN PEMBAHASAN}

1. Nilai Nasionalisme Dalam Ajaran Saminisme

a. Nilai Kesatuan

Nilai kesatuan ditunjukan dalam ajaran Samin yaitu "Ojo mbedo mbedakne sapodo padaning urip, kabeh iku sedulure dewe (Jangan membeda-bedakan sesama makhluk hidup, semua itu saudara)" Ajaran Samin dalam hal ini mengajarkan untuk tidak membeda-bedakan sesama mahkluk hidup dan menganggap bahwa semua makhluk hidup adalah saudara baik itu manusia, hewan ataupun tumbuhan. Semuanya harus bisa saling melindungi dan menyayangi serta tidak boleh mencelakai atau bahkan menindas antar sesama. atas dasar inilah yang menyebabkan munculnya masyarakat Samin yang mana didasari adanya penindasan yang dilakukan Kolonialisme Belanda terhadap Indonesia. Lebih lanjut lagi nilai Kesatuan dalam ajaran Samin disampaikan oleh Mbah Sampan selaku sesepuh masyarakat Samin mengatakan bahwa "Samin iku sami-sami rasane sami-sami bangsane, bapak kulo ngeh lanang, bapake jenengan ngeh lanang, ibuke jenengan ngeh wedok, ibuk kulo ngeh wedok. Jadi sami-sami rasane, sami bangsane, mboten enten bedane. Prinsipe sedulur sikep iku kejujuran, kesabaran, jadi tiang iku mek jujur, sabar kan slamet. (samin itu, sebangsa dan serasa, bapak saya laki-laki, begitu juga dengan bapak kalian, ibu kalian perempuan, begitu juga dengan ibu saya. Jadi sama satu bangsa, dan satu rasa. Semua tidak ada bedanya. Prinsip sedulur sikep itu menjalankan kejujuran dan kesabaran. Jadi orang itu kalau

\section{Paris Langkis}

Vol.1 Nomor 2, Maret 2021 
jujur dan sabar pasti akan selamat.) Berdasarkan pernyataan tersebut dengan jelas menjelaskan bahwa dalam ajaran Samin terdapat nilai kesatuan yang menjadi dasar terciptanya gerakan masyarakat Samin.

b. Nilai Solidaritas

Nilai solidaritas ditunjukan dalam ajaran Samin yaitu "Biso roso rumongso (Bisa saling mengerti satu dengan yang lain)”. Ajaran Samin dalam hal ini mengajarkan untuk saling mengerti satu sama lain. maksudnya adalah apabila ada orang lain membutuhkan bantuan itu dengan ikhlas untuk membantunya tanpa mengharapkan imbalan. Karena anggapan bahwa semua makhluk hidup adalah saudara maka keikhlasan untuk bisa saling tolong menolong selalu diutamakan. Dalam hal ini juga tidak boleh adanya paksaan kepada siapapun untuk menuruti kehendak atau keinginan yang memaksa, jadi masyarakat Samin pun juga tidak boleh memaksa kepada siapapun untuk ikut ajaran Samin, karena dalam ajaran samin tidak ada unsur paksaan untuk mengikuti ajaran tersebut. Dipertegas dengan pernyataan Mbah Sampan selaku sesepuh masyarakat Samin yang menyatakan bahwa "“nek sampean tekokne ngeh ngoten niku, dadi angone iku neng roso kimeng, gotong royong, tau ngewangi yo tau diewangi (kalau kamu tanyanya begitu, jadi sumbernya ada di rasa atau kesadaran, gotong royong, pernah membantu juga pernah dibantu)". Berdasarkan pernyataan tersebut dengan jelas menjelaskan bahwa ajaran Samin ini terdapat nilai solidaritas yang menimbulkan budaya gotong royong dan saling peduli satu sama lain.

c. Nilai Kemandirian

Nilai kemandirian yang terdapat pada ajaran Samin adalah menganggap bahwa semua manusia itu adalah saudara dan wajib untuk saling melindungi satu sama lain, tidak boleh menyakiti atau bahkan menindas orang lain. nilai kemandirian ini juga tak lepas dari cikal bakal munculnya masyarakat Samin yaitu karena penindasan yang dilakukan penjajahan Belanda. Ajaran ini mengajarkan untuk menolak terhadap pemimpin yang bukan dari bangsa Indonesia sendiri. sehingga mereka melakukan perlawanan terhadap penjajahan Belanda. jadi ajaran Samin menginginkan suatu kemerdekaan atau kebebasan untuk menentukan nasib sendiri dimasa depan.

Berdasarkan tiga bentuk nilai Nasionalisme dalam ajaran Saminisme tersebut dapat diambil benang merah bahwa terdapat beberapa faktor yang menyebabkan timbulnya Nasionalisme tersebut. Faktor tersebut yaitu menghendaki terciptanya suatu tujuan yaitu persatuan dan kesatuan dalam masyarakat serta mewujudkan bangsa Indonesia sebagai bangsa yang mandiri yang terbebas dari praktik penjajahan. Ditambah lagi dalam ajaran Samin juga mengajarkan mengenai semua makhluk hidup itu adalah saudara sehingga tidak boleh menyakiti ataupun sampai menindas satu sama lain. Maka dari itu ajaran Samin atau Saminisme ini merupakan suatu ajaran yang timbul sebagai bentuk perlawanan terhadap berbagai bentuk penindasan.

\section{Pendapat Masyarakat Samin Terhadap Keberadaan Teknologi Dan Informasi}

Perkembangan teknologi dan informasi yang sejalan dengan perkembangan arus globalisasi tidak dapat dibendung oleh siapapun di dunia ini. Sebab, perkembangannya selaras

\section{Paris Langkis}

Vol.1 Nomor 2, Maret 2021 
dengan perkembangan zaman yang semakin maju dari tahun ketahun. Perkembangan teknologi dan informasi terjadi secara cepat dan luas melintasi batas-batas negara tanpa ada yang bisa membendungnya. Akibatnya seluruh manusia di dunia ini baik yang tinggal di belahan benua manapun atau di tempat yang terpencil sekalipun pasti akan merasakan arus perkembangan teknologi dan informasi. Sehingga pengaruh yang ditimbulkan juga turut tidak bisa dihindari oleh siapapun.

Perkembangan teknologi dan informasi juga dirasakan dalam kehidupan keseharian masyarakat Samin Dusun Jepang, Desa Margomulyo. Hal ini ditunjukan dengan pemakaian berbagai teknologi modern yang mereka manfaatkan dalam aktivitas mereka sehari-hari. pemanfaatannya yaitu dalam bidang pertanian yang berupa pemakaian pupuk kimia untuk bercocok tanam, pemakaian traktor untuk membajak sawah, pemakaian mesin pemotong singkong untuk memotong singkong dan pemakaian teknologi lainya. Selain itu di bidang komunikasi dan informasi juga telah ditunjukan dengan pemakaian Televisi yang hampir ada di tiap rumah di Dusun Jepang dan pemakaian Handphone untuk berkomunikasi. pemanfaatan teknologi dan informasi pada masyarakat Samin juga dilakukan pada bidang-bidang lainnya yang mana dari pemanfaatannya tersebut dapat memudahkan aktivitas sehari-hari. Dalam hal ini masyarakat Samin diuntungkan dengan pemakaian teknologi seperti dalam memecahkan permasalahan yaitu dalam hal efisiensi waktu dan kemudahan dalam beraktifitas.

Perkembangan teknologi dan informasi pada masyarakat Samin sejatinya dimulai pada saat masyarakat Samin mengetahui bahwa Indonesia telah merdeka. Akan tetapi mereka terlambat mengetahuinya dikarenakan mereka tinggal di tempat terpencil di pinggiran hutan. Sehingga Surokarto Kamidin yang merupakan sesepuh masyarakat Samin pada saat itu berangkat ke Jakarta untuk menemui Presiden Sukarno untuk menanyakan langsung perihal kebenarannya. Alhasil setelah kepulangannya dari Jakarta, Surokarto Kamidin menyampaikan kepada pengikutnya mengenai kebenaran bahwa Indonesia sudah merdeka sehingga tidak perlu melakukan perlawanan. Maka atas dasar itu masyarakat Samin mulai membuka diri dengan dunia luar termasuk membuka diri dengan masuknya berbagai teknologi dan informasi. Sesuai dengan pernyataan mbah Harjo Kardi dalam buku cerita mbah Surokarto Kamidin tentang pesan dari mbah Surosentiko yang menyatakan bahwa "Karena mendengar negara sudah merdeka Surokarto Kamidin pergi ke Jakarta menghadap Pak Karno (Sukarno). Disana dia bertanya tentang kebenarannya peraturan yang sedang dijalankan. Sepulangnya dari Jakarta dia langsung memberitahukan kepada anak cucunya supaya taat kepada pemerintah karena yang memerintah sudah bangsa Indonesia (Orang Jawa diperintah oleh orang Jawa sendiri)".

Proses masuknya teknologi dan informasi dalam kehidupan masyarakat Samin dimulai berbarengan dengan agenda pembangunan oleh pemerintah. Agenda pembangunan tersebut seperti pembangunan dalam bidang pertanian dan pendidikan. Di bidang pertanian mulai masuknya traktor, pupuk kimia dan pemakaian bibit unggul, selanjutnya dalam bidang pendidikan ditunjukan dengan mulai dibangunnya Sekolah Dasar di Dusun Jepang yang pada awalnya diperuntukan untuk mengurangi angka buta huruf masyarakat Dusun Jepang. Senada dengan pernyataan bapak Sukijan selaku Kepala Dusun Jepang yang menyatakan bahwa "Waktu itu kalau tidak salah sekitar tahun 70an disini sudah mulai ada bantuan pupuk, bibit,

\section{Paris Langkis}

Vol.1 Nomor 2, Maret 2021 
traktor. Itu seadanya dipakai sama-sama bagi yang ingin pakai. Tapi alhamdulilah bisa membantu meskipun ya kurang gitu. Disini hampir semuanya petani jadi ya bersyukur bila ada itu, bisa membantu". Pernyataan tersebut ditambah dengan pernyataan Harjo Kardi dalam buku cerita mbah Surokarto Kamidin tentang pesan dari mbah Surosentiko yang menyatakan bahwa "Pada saat itu Dusun Jepang termasuk daerah yang buta huruf karena belum ada sekolahan. Ada sekolahan tetapi letaknya jauh di Desa Sumberjo. Jadi kalau mau sekolah mereka menempuh jalan yang jauh dan melewati hutan. Dengan perkembangan jaman akhirnya di Dusun Jepang terdapat sekolah meskipun bertempat dirumah penduduk. Setelah orde baru dengan bertambah majunya pemerintahan akhirnya Harjo Kardi bermusyawarah dengan masyarakat untuk mendirikan sekolahan yang resmi. Akhirnya dengan semangat yang dimiliki oleh masyarakat dan didukung oleh Harjo Kardi sekolahan yang dicita-citakan dapat terwujud. Sekolahan tersebut dimiliki oleh empat Dusun yaitu Jepang, Kaligede, Tepus dan Batang."

Semakin tahun ke tahun Dusun Jepang mulai bertambah maju dan modern yang ditunjukan dengan mulai masuknya listrik pada tahun 1999, kemudian sinyal telepon pada tahun 2007 yang dibarengi dengan teknologi lain seperti Handphone, Televisi, dan Sepeda Motor. Selanjutnya perkembangan Dusun Jepang menjadi semakin maju dan modern dengan cepat seiring dengan pembangunan Desa Wisata Budaya Margomulyo yang menawarkan budaya masyarakat Samin sebagai destinasi atau objek pariwisata. Sehingga dari hal ini mulai dibangunanya berbagai fasilitas penunjang pariwisata seperti penginapan, bumi perkemahan dan fasilitas penunjang lainnya. Selain itu dari proyek pembangunan ini juga menyebabkan banyaknya masyarakat luar yang berkunjung di Dusun Jepang yang mana masyarakat dari luar ini membawa kebiasaan atau kebudayaan dari luar sehingga turut serta mempengaruhi kehidupan masyarakat Samin.

Pengaruh dari masuknya teknologi dan informasi yang masuk ke Dusun Jepang, telah memunculkan perubahan-perubahan dalam kehidupan masyarakat Samin. perubahan tersebut meliputi: (1) pakaian, dalam hal ini telah terjadi perubahan dari masyarakat Samin yang mana kebanyakan dari mereka telah berpenampilan seperti msyarakat biasa pada umumya, padahal masyarakat Samin ini mempunya pakaian adat sendiri yaitu memakai kaos hitam lengan panjang dan celana hitam bagi laki-laki dan memakai kemeja khas Jawa bagi Perempuan: (2) Pendidikan, dalam hal ini ditunjukan masyarakat Samin yang bersekolah, padahal dulunya masyarakat Samin menolak pendidikan; (3) Profesi, dalam hal ini ditunjukan telah ada masyarakat Samin yang berprofesi sebagai PNS, Guru, Buruh pabrik, Polisi dan bahkan Pedagang, padahal profesi pedagang adalah profesi yang tidak diperbolehkan dalam masyarakat Samin karena identik dengan ketidak jujuran; (4) Pernikahan, pernikahan adat masyarakat Samin saat ini telah berubah yang mana terdapat pendaftaran ke KUA setelah prosesi pernikahan adat (5) Tempat tinggal, dalam hal ini ditunjukan akan perubahan tempat tinggal masyarakat Samin yaitu Dusun Jepang sebagai tempat pariwisata yang terkenal dan banyak dikunjungi orang, padahal dulunya Dusun Jepang adalah tempat yang terpencil dan tidak banyak dikenal orang; (6) Bahasa, masyarakat Samin dalam hal ini telah banyak yang menguasai bahasa selain bahasa Jawa, yaitu Bahasa Indonesia dan bahasa Inggris; (7) Agama, masyarakat

\section{Paris Langkis}

Vol.1 Nomor 2, Maret 2021 
Samin telah banyak yang memeluk agama Islam ditunjukan dari adanya mushola dan masjid di Dusun Jepang, padahal masyarakat Samin terkenal karena kepercayaan abangan (kejawen); dan (8) kehidupan sehari-hari, dalam hal ini ditunjukan dengan penggunaan berbagai macam teknologi dalam kehidupan mereka.

Berdasarkan pengaruh dari masuknya teknologi dan informasi tersebut dapat diambil kesimpulan bahwa perubahan tersebut merupakan dampak negatif dari perkembangan teknologi dan informasi. Akan tetapi selain dampak negatif, juga terdapat dampak positif yakni perubahan pada pemikiran mereka yang mana lebih modern. Selain itu mereka juga berpendapat bahwa kehadiran teknologi dan Informasi dalam kehidupan mereka dapat mempermudah pekerjaan mereka sehari-hari, sehingga mereka dapat menerima dengan baik teknologi dan informasi yang masuk.

\section{Penerapan Nilai Nasionalisme Di Era Kemajuan Teknologi Dan Informasi Pada Masyarakat Samin}

Masyarakat Samin Dusun Jepang merupakan masyarakat yang bertempat tinggal di daerah terpencil telah dimasuki oleh arus perkembangan teknologi dan informasi. Hal ini dibuktikan dengan pemakaian berbagai macam teknologi yang mereka gunakan dalam kehidupan mereka. Disamping itu masyarakat Samin masih tetap berpegang teguh terhadap ajaran yang dianutnya yaitu ajaran Saminisme yang salah satu isinya adalah menyangkut nilai-nilai Nasionalisme. Masyarakat Samin sampai saat ini masih melaksanakan nilai Nasionalisme yang mana mereka lakukan atas dasar implementasi dari ajaran Saminisme yang mereka anut. Mereka melakukannya dalam berbagai perilaku di kehidupan kesehariannya baik itu perilaku yang tampak atau perilaku yang tidak tampak. Perilaku-perilaku yang tampak pada masyarakat Samin yaitu sebagaimana mereka lakukan dalam kehidupan kesehariannya, sedangkan untuk perilaku yang tidak tampak seperti contohnya yaitu bagaimana mereka beragama atau bertuhan.

Penerapan nilai Nasionalisme masyarakat Samin pada era kemajuan teknologi dan informasi terwujud dalam perilaku yang selaras dengan bentuk-bentuk nilai Nasionalisme, yakni terdiri dari nilai kesatuan, solidaritas dan kemandirian. Penerapan nilai kesatuan terwujud dalam perilaku-perilaku yang meliputi: (1) Menjaga ketertiban masyarakat dengan mematuhi aturan yang berlaku. Dalam hal ini tercermin dalam perilaku mematuhi dan mengajak masyarakat umum untuk mematuhi protokol kesehatan Covid-19, memanfaatkan tanah milik perhutani tanpa merusak tanah milik perhutani dan Rajin membayar pajak; (2) menghormati dan tidak membeda-bedakan sesama. Hal ini tercermin dalam perilaku sopan dan santun ketika berbicara, terbuka menerima seluruh masyarakat yang berkunjung ke Dusun Jepang, dan menggunakan bahasa Jawa Ngoko Lugu dalam berkomunikasi yang mana bahasa ini identic dengan prinsip egaliter atau sederajat.

Bentuk nilai Nasionalisme yang kedua dalam ajaran Saminisme yaitu nilai solidaritas. Penerapan nilai ini terwujud dalam perilaku gotong royong dan saling tolong menolong, Perilaku ini merupakan perilaku yang merupakan implementasi dari ajaran Saminisme yang mengajarkan untuk saling tolong menolong satu dengan lain dan menganggap kalau semuanya

\section{Paris Langkis}

Vol.1 Nomor 2, Maret 2021 
itu adalah saudara. Pelaksanaan gotong royong dalam masyarakat Samin dilakukan dalam berbagai ketika yang meliputi: (1) Membangun dan memindahkan rumah; (2) Pertanian yakni ditunjukan dalam bercocok tanam, mencangkul sawah, membajak sawah serta kegiatan pertanian lain; (3) Ketika ada acara yang menyangkut daur hidup yakni pada saat terjadi peristiwa kehamilan, kelahiran, kematian dan lain-lain; (4) Membangun dan merawat sarana dan prasarana yang ada di Dusun Jepang yang meliputi pembangunan sumur air, pembangunan sekolah, kerja bakti membersihkan lingkungan dan lain-lain.

Bentuk nilai Nasionalisme yang ketiga yaitu nilai kemandirian. Penerapan nilai ini terwujud dalam perilaku-perilaku yang meliputi: (1) mencintai produk sendiri. hal ini ditunjukan dalam pemakaian alat-alat pertanian buatan sendiri, perabotan rumah tangga, pemakaian Bahasa jawa sebagai identitas mereka yakni orang jawa, masih dipakainya pakaian adat masyarakat Samin, dan masih melaksanakan tradisi yang diwariskan dari leluhur mereka secara turun temurun; (2) Aktif dalam pembangunan bangsa dan negara yang ditunjukan dengan aktif mengikuti pemilu serentak pada tahun 2019 dan mereka juga aktif dalam melaksanakan pembangunan di daerah mereka yang meliputi membangun sumur air untuk persediaan air bersih, membangun jaringan wifi hotspot untuk mengatasi sinyal yang kurang bagus di Dusun Jepang dan membuat media sosial yang digunakan untuk promosi Desa Wisata Samin Bojonegoro.

Berdasarkan perilaku-perilaku yang merupakan wujud dari pelaksanaan nilai Nasionalisme tersebut, masyarakat Samin dalam berperilakunya sudah tidak sama lagi dengan mereka yang dahulu melakukan perlawanan kepada penjajahan Belanda tetapi sekarang perilaku tersebut mereka lakukan dengan tujuan membangun persatuan dan kesatuan bangsa serta untuk memajukan bangsa. Mereka melakukannya karena dari kecil sudah ditanamkan ajaran Samin yang salah satu isinya adalah Nasionalisme sehingga membentuk perilaku-perilaku tersebut ditambah lagi dengan adanya pengaruh dari lingkungan. Perilaku tersebut mereka lakukan dikarenakan adanya stimulus dari ajaran Samin dan adanya pengaruh dari lingkungan yang telah dimasuki oleh arus globalisasi yang membawa perkembangan teknologi dan informasi. Ditambah karena dipengaruhi oleh kondisi lingkungan yang telah dimasuki oleh masuknya teknologi dan informasi yang mana membawa kebudayaan baru dari luar, Sehingga kebudayaan tersebut mulai perlahan mempengaruhi kebudayaan masyarakat Samin itu sendiri. Maka dari itu perubahan mulai terjadi dalam kehidupan masyarakat Samin termasuk adalah perubahan perilaku Nasionalisme yang masyarakat Samin terapkan.

Selain beberapa faktor tersebut, perilaku masyarakat Samin juga dipengaruhi oleh beberapa faktor lain yang turut serta mempengaruhi perilaku dari masyarakat Samin. faktor tersebut yaitu adanya ajaran Samin yang merupakan ajaran yang disampaikan turun temurun dari pendahulunya serta perilaku dari sesepuh masyarakat Samin yang menjadi contoh bagi pengikut-pengikut ajaran Samin. Sehingga dari beberapa faktor tersebut dapat mempengaruhi pengetahuan dan kehendak untuk bertindak atau berperilaku dari masyarakat Samin sehingga menyebabkan mereka berperilaku seperti itu.

Proses pembentukan perilaku yang dilakukan oleh masyarakat Samin terjadi dikarenakan adanya refleksi dari gejala kejiwaan dari masyarakat Samin. Proses tersebut diakibatkan karena

\section{Paris Langkis}

Vol.1 Nomor 2, Maret 2021 
pengetahuan yang didapat oleh sesepuh Masyarakat Samin serta pengetahuan yang didapat dari kondisi dalam kehidupan kesehariannya yang telah dimasuki oleh berbagai arus dari perkembangan teknologi. Serta terdapat keinginan, motivasi dan minat dari masyarakat tersebut untuk berperilaku yang ditunjukan dengan pemakaian barang-barang dari luar yang baru masuk kedalam kehidupan dan barang-barang tersebut bisa meringankan pekerjaan mereka dalam kesehariannya. Sehingga dari hal tersebut, masyarakat Samin melakukan pengadopsian perilaku baru.

Pengadopsian perilaku baru dilakukan oleh masyarakat Samin yang mereka lakukan dalam beberapa langkah. Langkah-langkah tersebut yaitu yang pertama adalah masyarakat Samin menyadari bahwasannya terdapat rangsangan atau stimulus yang berupa ajaran Samin, lingkungan sekitar serta kondisi pada saat terjadinya stimulus. Selanjutnya adalah tahap dimana masyarakat Samin mulai menunjukan rasa ketertarikan kepada rangsangan atau stimulus tersebut, dalam hal ini bisa dicontohkan karena terdapat hal baru dan dirasa lebih bagus atau lebih bermanfaat yang masuk kedalam kehidupan mereka sehingga menyebabkan ketertarikan. Selanjutnya tahap mengukur baik atau buruknya stimulus tersebut yaitu apabila lebih baik atau lebih buruk untuk dirinya sendiri, jadi pada tahap ini bisa dikatakan bahwa masyarakat Samin sebelum berperilaku, mereka menimbang baik atau buruknya untuk diri mereka seperti halnya ketika masuknya arus perkembangan teknologi dan informasi yang mana hal ini juga dapat bermanfaat dalam membantu pekerjaan mereka dalam kesehariannya. Sehingga masyarakat Samin mulai mencoba perilaku yang baru. Masyarakat Samin setelah arus perkembangan teknologi dan informasi mulai memasuki kehidupan mereka, mereka mulai melakukan perilaku baru, dalam hal ini bisa dicontohkan ketika masuknya berbagai teknologi dan arus dari perkembangan zaman dalam kehidupan mereka. Mereka mulai banyak yang bersekolah, mereka mulai menggunakan berbagai teknologi sera mereka mulai mau membangun dan turut serta memajukan tempat tinggal mereka sesuai perkembangan zaman yang mana tanpa mengurangi esensi dari ajaran yang mereka anut yaitu ajaran Saminisme.

Berdasarkan penjelasan tersebut dapat disimpulkan bahwa masyarakat Samin pada awalnya menerapkan perilaku Nasionalisme yang berbentuk Nasionalisme etnik yang awalnya ditunjukan dengan kesamaan dalam Bahasa, budaya, dan kesamaan nasib dijajah oleh penjajah Belanda. Sehingga pada waktu itu munculah rasa Nasionalisme mereka untuk berjuang melawan penjajahan Belanda. Kemudian selanjutnya ketika Indonesia telah merdeka barulah berubah menjadi Nasionalisme yang berbentuk Nasionalisme Kewarganegaraan yang ditunjukan dengan ketaatan mereka pada pemerintah Indonesia dan ingin membangun dan memajukan Indonesia serta menjaga kesatuan dan persatuan bangsa Indonesia. Masyarakat Samin saat ini mulai mau untuk sekolah, bekerja selain bertani, dan berbagai hal lainya yang sesuai dengan perkembangan zaman. Bahkan masyarakat Samin menggunakan teknologi dan Informasi untuk membentuk persatuan dan kesatuan bangsa Indonesia serta mengajak kepada semua orang untuk berpartisipasi membangun Indonesia dengan gotong royong.

\section{E. KESIMPULAN}

1. Nilai Nasionalisme dalam ajaran Saminisme yaitu terdapat tiga bentuk yang terdiri dari nilai

\section{Paris Langkis}

Vol.1 Nomor 2, Maret 2021 
kesatuan, nilai solidaritas dan nilai nilai kemandirian. Nilai kesatuan dalam ajaran Samin yaitu mengajarkan bahwa semua orang itu saudara dan semua makhluk hidup itu adalah sama atau sejajar, tidak boleh membeda-bedakan satu sama lain. Nilai solidaritas dalam ajaran Samin yaitu mengajarkan bahwa semua orang harus mengerti satu sama lain yaitu tidak boleh ada pemaksaan kehendak atau mencelakai satu sama lain serta adanya perasaan untuk saling menolong satu sama lain. Yang selanjutnya nilai kemandirian dalam ajaran Samin yaitu mengajarkan bahwa semua orang atau bangsa itu bebas mengatur segala urusan pribadinya yang mana tidak boleh ada pemaksaan kehendak atau bahkan memperbudak seseorang.

2. Pendapat masyarakat Samin terhadap keberadaan teknologi dan informasi yaitu masyarakat menganggap bahwa kehadiran teknologi dan informasi dapat memudahkan kinerja mereka dalam sehari-hari sehingga mereka menerima masuknya teknologi dan informasi dalam kehidupan mereka.

3. Perilaku-perilaku Nasionalisme yang diterapkan dalam keseharian masyarakat Samin yaitu lebih kepada upaya menjaga kesatuan dan persatuan bangsa serta bagaimana memajukan bangsa Indonesia. Perilaku-perilaku tersebut adalah gotong royong dan saling tolong menolong, mencintai dan memakai produk sendiri meskipun sebagian sudah memakai produk buatan luar, menjaga ketertiban masyarakat dengan mematuhi aturan yang berlaku, menghormati dan tidak membeda-bedakan sesama dan turut aktif dalam pembangunan bangsa dan negara.

\section{F. SARAN}

1. Untuk pemerintah Desa Margomulyo dan pemerintah Kabupaten Bojonegoro diharapkan untuk memperhatikan pengaruh atau dampak dari pembangunan pariwisata yang dilakukan di Dusun Jepang yaitu dengan tidak menghilangkan kearifan lokal yang ada pada masyarakat Samin.

2. Untuk masyarakat Bojonegoro diharapkan untuk mengetahu dan mengerti tentang masyarakat Samin di Dusun Jepang terutama mengenai ajaran-ajaran yang mereka wariskan secara turun temurun agar dapat juga diambil hal-hal yang baik seperti berperilaku kejujuran, kesabaran, keiklasan, tanpa membeda-bedakan sesama dan lain-lain.

3. Untuk pembaca dan penelitian lanjutan diharapkan dapat secara detail memahami akan nilai-nilai yang dibahas dalam fokus penelitian ini. Selain itu, agar dapat lebih memperjelas serta memfokuskan apa yang dapat diambil dari penelitian ini, sehingga hasil yang diperoleh akan maksimal.

\section{REFERENSI}

Adisusilo, S. (2010). Nasionalisme - Demokrasi - Civil Society. Jurnal Dimensia. https://www.usd.ac.id/lembaga/lppm/f113/Jurnal Historia Vitae/vol23no2oktober2009/NASIONALISME sutarjo adisusilo.pdf

Alfaqi, M. Z. 2015. Memahami Indonesia Melalui Prespektif Nasionalisme, Politik Identitas, Serta Solidaritas. Jurnal Pendidikan Pancasila Dan Kewarganegaraan, 282, 111-116. http://journal.um.ac.id/index.php/jppk/article/view/5451/2120

\section{Paris Langkis}

Vol.1 Nomor 2, Maret 2021 
Anas, M. 2017. Kewarganegaraan Identitas, Kebangsaan, dan Nilai Keindonesiaan. Malang: Madani.

Arifin, Zaenal \& Setiyawan, Adhi. (2012). Pengembangan Pembelajaran Aktif Dengan ICT. Yogyakarta: T. Skripta Media Creative.

Budiman, A. (2006). Kebebasan, Negara, Pembangunan (Kumpulan Tulisan 1965-2005). Jakarta: Pustaka Alvabet.

Lestari, I. P. (2013). Interaksi Sosial Komunitas Samin Dengan Masyarakat Sekitar. Komunitas: International Journal of Indonesian Society and Culture, 5(1), 74-86. https://doi.org/10.15294/komunitas.v5i1.2376

Munawaroh, S., Ariani, C., \& Suwarno. 2015. Etnografi masyarakat Samin di Bojonegoro: potret masyarakat Samin dalam memaknai hidup. Yogyakarta: Balai Pelestarian Nilai Budaya BPNB.

Mustari, M. 2011. Nilai Karakter Refleksi Untuk Pendidikan Karakter. Yogyakarta: Laksbang Pressindo.

Nasution, R, S. 2017. Pengaruh Perkembangan Teknologi Informasi Komunikasi Terhadap Eksistensi Budaya Lokal. Jurnal Penelitian Komunikasi dan Opini Publik, 211. http://eprints.umpo.ac.id/5056/3/\%28plagiasi\%29\%20Pengaruh\%20Perkembangan\%20Te knologi\%20Informasi\%20Komunikasi\%20Terhadap\%20Eksistensi\%20Budaya\%20Lokal.pdf

Norhalisa, L., Eddy. Dotrimensi. (2020). Makna Sepundu Bagi Masyarakat Agama Hindu Kaharingan Dalam Upacara Tiwah Di Desa Tumbang Manjul Kecamatan Seruyan Hulu Kabupaten Seruyan. Jurnal Paris Langkis, 1 1(1), https://e-journal.upr.ac.id/index.php/parislangkis/article/view/1666

Sholichiyah, I. (2014). Nilai-Nilai Nasionalisme dalam Film Sang Kyai. IAIN Wali Songo Semarang. Supriadi, A., Matnuh, H., \& Mitha. 2014. Internalisasi Nilai Nasionalisme Dalam Pembelajaran PKN Pada Siswa MAN 2 Model Banjarmasin. Jurnal Pendidikan Kewarganegaraan, 48.

Wardiah, M. L. (2016). Teori Perilaku dan Budaya Organisasi. Bandung: Cv Pustaka Setia.

Widyatwati, K. (2017). Pengaruh Masuknya Budaya Populer terhadap Eksistensi Ajaran Sedulur Sikep Pada Masyarakat Samin. Nusa: Jurnal Ilmu Bahasa Dan Sastra, 12(1), 137. https://doi.org/10.14710/nusa.12.1.137-146

\section{Paris Langkis}

Vol.1 Nomor 2, Maret 2021 